UDC 620.171.3:616.71-001.5

\title{
INFLUENCE OF BONE TISSUE REGENERATE ON RIGIDITY OF FRACTURES FIXATION
}

\author{
M. S. Shidlovskiy \\ O. S. Musiienko \\ O. P. Zakhovaiko \\ Yu. A. Lisachenko \\ National Technical University of Ukraine "Igor Sikorsky Kyiv Polytechnic Institute" \\ Peremogy ave., 37, Kyiv, 03056
}

DOI: $10.32347 / 2410-2547.2021 .107 .89-102$

\begin{abstract}
Based on experimental studies, an analytical method is proposed for an estimation of the influence of a regenerate of a bone fabric on rigidity of the system of osteosynthesis.

A method for the experimental determination of displacements in the fracture region under the action of loads taking into account the regenerate has been developed and tested.

A number of experiments were performed in compression, bending and torsion to determine the deformation characteristics of systems without regenerate and in its presence.

The results of experiments related to the influence of bone regenerate formed during the fusion of fractures on the mechanical characteristics of the system "bone with a fracture - a means of fixation" are described. To assess the impact of bone regeneration, a method for studying the deformation of osteosynthesis systems using the method of modeling bone regeneration with a polymeric material with specified properties was developed and implemented.

Using the stiffness condition, the expression for the calculation of permissible loads that do not lead to dangerous displacements of fracture points is obtained. The reduced deformations and permissible loads for the systems "bone with a fracture - a means of fixation" at different stages of bone tissue (BT) regeneration under the action of compression, bending and torsion are calculated. It is established that the formed regenerate significantly increases the rigidity of the system "bone with a fracture - bone regenerate - a means of fixation", which increases the level of allowable loads on the extremities at different stages of treatment.

Test and calculation data can be used to improve methods of treatment of damaged limbs in the intermediate and final stages of fracture fusion.
\end{abstract}

Keywords: bone regenerate; rigidityof systems; osteosynthesis, biomechanical characteristics, tibia, compression, bending, torsion, permissible load.

Introduction. Bone regenerate (BR), which is formed during the fusion of bone fractures [1-3], can significantly affect the deformation of the osteosynthesis system (OS). The load acting on the human limb during walking and therapeutic exercises is transferred not only to the means of fixation, but also partially perceived by the BR. Due to this, the permissible loads on the limb can be increased compared to the initial stages of fracture fusion.

To date, we do not know any experimental studies related to the effect of BR on the rigidity of the systems "bone with fracture - a means of fixation". In the known experimental studies, the mutual displacements of fracture points were determined on full-scale bone samples with simulated fractures with diastases (gaps between fracture fragments) that were not filled with BR. This condition corresponds only to the initial stages of fracture fusion, when BR is

(C) Shidlovskiy M.S., Musiienko O.S., Zakhovaiko O.P., Lisachenko Yu.A. 
absent or its mechanical properties do not affect the deformation (displacement) of fracture points under the action of physiological loads. In this case, the values of permissible loads determined using these experiments also correspond only to the initial state of the BR. To determine the permissible loads for the later stages of fracture fusion, it is necessary to know the peculiarities of changes in the deformation properties of BT in the fracture area, taking into account the processes of its regeneration.

This paper describes the results of experiments related to the influence of $\mathrm{BR}$, formed during the fusion of fractures, on the mechanical characteristics of the system "bone with a fracture - a means of fixation". To assess the impact of $\mathrm{BR}$, a method for studying the deformation of osteosynthesis systems using the method of modeling BR by polymer material with specified properties was developed and implemented.

Basic patterns of bone regeneration.Bone is a complex organ that performs mechanical and biological functions in the human body and has a complex hierarchical structure. It is a dynamic polymorphic system in which two interrelated processes take place during a person's life, which make up the cycle of bone remodeling - resorption (destruction of the old bone) and osteogenesis (formation of the new one) [4]. Therefore, BT and the conditions of its reparative regeneration are constantly in the field of view of traumatologists and orthopedists. Reparative regeneration is the restoration of tissue after its damage. Mechanisms of physiological and reparative regeneration are qualitatively uniform and are carried out on the basis of general laws [4].

Reparative regeneration of each type of tissue has its own characteristics, but always includes the processes of disintegration of damaged cells and intercellular substance, proliferation of viable cells, their differentiation, the establishment of intercellular connections - i.e., integration and adaptation of regeneration. BR is unique because it is able to completely restore even large-scale defects [5].

It is known that reparative BT regeneration is a complex, genetically programmed process. The stage-time characteristics of this process depend on the action of a number of endogenous and exogenous factors. The course of osteoreparative process is mostly associated with the features and intensity of injury, the nature of bone and soft tissue damage, the degree of post-traumatic disorders of peripheral blood supply, the quality of primary and qualified medical care, features of rehabilitation treatment, the presence of aggravating concomitant pathology [4].

Consolidation of fractures is carried out by indirect bone regeneration, which consists of several successive stages - 1) inflammation (begins immediately after the injury and lasts up to five days); 2) formation of soft corns (replacement of hematoma with fibrocartilage tissue lasting up to 40 days); 3) the formation of hard calluses (bone bridges are formed between fragments of broken bone); 4) remodeling (restoration of the original shape, structure and mechanical strength of the bone). Violation of any course from these stages can lead to a slowdown in the process of osteoreparation or even non-healing of bone fragments. 
Therefore, the problem of BT regeneration occupies a special place in the system of biological and medical knowledge. To date, a distinctive feature of BT regeneration has been identified, and some progress has been made in elucidating the biological mechanisms underlying reparative osteogenesis, and the main trends in the development of the direction have been formulated[5].

\section{Research methodology}

The essence of the method. The use of full-scale objects with formed areas of BR for experiments is not possible, so for research we used bone samples with simulated fractures, fracture fixation systems [6-11] and simulated BR.

The tibia with a simulated fracture and fixative was installed on the platen of the test machine and subjected to compression, bending and torsion tests [10,11].

Previously, elastic materials were installed in diastasis (the interval between fracture fragments), which simulated regenerative bone tissue [1, 12].

Test object and supporting materials. The object of the research was a tibia with a simulated fracture fixed by a medial tibial blocked plate [9-11]. The system "bone with a fracture - simulated BR - fixative" was installed on the platen of a test machine. Previously, diastasis (the space between the fracture fragments) was filled by material simulating BR.

Determination of modulus of elasticity for these materials or mixtures was performed on cylindrical samples with a diameter of $12 \mathrm{~mm}$ by compression testing using a universal testing machine type TIRA-test with simultaneous application of load and recording of deformation diagrams.

Using data on X-ray density and modulus of elasticity of different types of BT $[7,8]$, a number of polymeric materials with equivalent characteristics were selected for modeling BR in the early stages of regeneration.

To replace the regenerative bone tissue at the previous stage of research were used: rubber RP-101 (modulus of elasticity under compression $E=7.74 \ldots 8.71 \mathrm{MPa})$; high-density foam $(E=0.6 \ldots 0.8 \mathrm{MPa})$; low density foam $(E=0.2 \ldots 0.4 \mathrm{MPa})$; foam rubber $(E=0.05 \ldots 0.08 \mathrm{MPa})$.

UniCast 9 polyurethane and SILVER 20 silicone were also used to model the BR. These polymers are able to change some mechanical characteristics, in particular the modulus of elasticity, at different ratios of components "A"(resin) and "B"(hardener). Compression tests of the samples gave the following results: polyurethane "UniCast 9" - mixture 1 (ratio of components "A" and "B" 100: 50) modulus of elasticity under compression $E=710 \ldots 790 \mathrm{MPa}$; mixture 2 (100: 25) $E=14.8 \ldots 15.6 \mathrm{MPa}$; mixture $3(75: 50) E=670 \ldots 730 \mathrm{MPa}$; silicone "SILVER 20" - a mixture of $4(100: 12,5) E=0.46 \ldots 0.54 \mathrm{MPa}$.

Only one mixture is made from silicone "SILVER 20", because component "B" acts only as a catalyst to accelerate the curing process of the polymeric material and its amount has virtually no effect on the stiffness of the material.

Mixtures № 1 and № 3 of polyurethane "UniCast 9" characterize the late stages of formation of bone regenerate, and mixtures № 2 and № 4 of silicone "SILVER 20" - early stages. As previous experiments have shown, when using UniCast 9 polyurethane mixtures № 1 and № 3 for BR modeling, the mutual displacements under the action of load are very small and do not exceed the 
measurement error. Therefore, the use of such materials due to their high hardness, in our opinion, is impractical.

The mixture 4 of silicone "SILVER 20" is also impractical to use, because it is quite difficult to adjust the modulus of elasticity of this material. Subsequently, a mixture № 2 of polyurethane "UniCast 9" was used in the experiment on the system "bone with fracture - simulated bone regenerate - fixative ".

Features of bones testing with fixed fractures. The method of testing for compression, bending and torsion of different types of plates for fixing fractures of tibia is described in $[6,9,14]$. When tested for off-center compression (Fig. 1a, b), the load $P=150 \mathrm{~N}$ was applied to the end of the rod with eccentricity relative to the surface of the fixing plate $e_{1}=17.5 \mathrm{~mm}$. For bending tests in the frontal plane of the bone (Fig. 1c, d) load $P=30 \mathrm{~N}$ was applied to the lateral surface of the bone at a distance of $e_{2}=32 \mathrm{~mm}$ from the fracture.

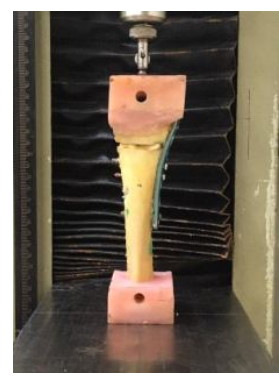

a

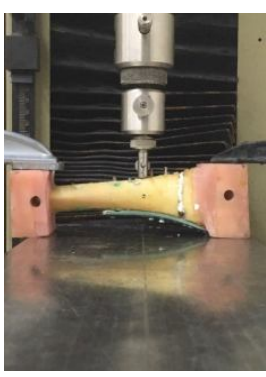

b



$\mathrm{c}$

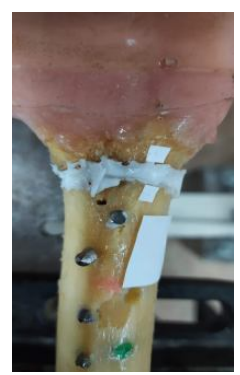

d

Fig. 1. Testing of the tibia with a simulated fracture fixed by a medial tibial blocked plate for compression (a), bending (b) and torsion (c); fracture filled with a polymeric material that simulates the regeneration of bone tissue

Simultaneously with the application of forces, the general diagrams of the system deformation were recorded. The displacement of the breakpoints $\Lambda$ under load $P$ was determined by the method of digital photography and computer image processing $[6,14]$. Similar tests were performed on tibia bones without simulating with unfilled diastase.

\section{Test results}

Tests using rubber, foam and styrofoam. Table 1 shows the results of measuring of the displacements of tibia with a fracture fixed by the medial tibial blocked plate. The results were obtained on three tibia samples of five measurements on each sample, followed by averaging of the data.

It is established that the presence of BR leads to a significant reduction in the mutual displacements of the fracture under the action of loads. The BR model with an elastic modulus of $8 \ldots 9 \mathrm{MPa}$ reduces the displacement at bending by $2 \ldots 2.4$ times, at bending - by $1.2 \ldots 1.9$ times.

As established during the tests, the use of foam, rubber and foam for modeling is not effective and convenient for further research. This is due to the inability to vary the modulus of elasticity of these materials for modeling BR. 
Table 1

\begin{tabular}{|c|c|c|}
\hline \multirow{2}{*}{$\begin{array}{c}\text { Material for regenerate } \\
\text { modeling }\end{array}$} & \multicolumn{2}{|c|}{ Mutual displacement of points fracture $\Lambda, \mathrm{mm}$} \\
\cline { 2 - 3 } & $\begin{array}{c}\text { Eccentric compression } \\
P=150 \mathrm{~N}\end{array}$ & $\begin{array}{c}\text { Bending } \\
P=30 \mathrm{~N}\end{array}$ \\
\hline Without regenerate & $0.69 \ldots 0.72$ & $0.11 \ldots 0.13$ \\
\hline Foam rubber & $0.68 \ldots 0,73$ & $0.12 \ldots 0.13$ \\
\hline Low density polyfoam & $0.58 \ldots 0.65$ & $0.10 \ldots 0.13$ \\
\hline High density polyfoam & $0.37 \ldots 0.40$ & $0.10 \ldots 0.12$ \\
\hline Rubber RP 101 & $0.30 \ldots 0.34$ & $0.07 \ldots 0.09$ \\
\hline
\end{tabular}

Tests using polyurethane. Subsequently, when conducting an experiment on the system "bone with fracture - simulated bone regenerate - fixative" we used a mixture of № 2 polyurethane "UniCast 9" with a modulus of elasticity $E=14.8 \ldots 15.6 \mathrm{MPa}$. In the tests for eccentric compression of the bone, forces $P=100,150$ and $200 \mathrm{~N}$ were applied, in the tests for bending in the frontal plane, forces $P=30,50$ and $70 \mathrm{~N}$ were applied to the lateral surface of the rod.

Absolute displacements $\Lambda$ of the medial (located near the plate) and lateral (farthest from the plate) points were determined. The above displacements $\lambda$ were defined as the ratio of the absolute mutual displacements of adjacent fracture points to the load $R$. The results of tests and calculations are given in table. 2, where $\lambda_{X}$ is the reduced displacement along the longitudinal axis of the bone, $\lambda_{Y}$ is the transverse displacement, $\lambda$ is thefull displacement.

Table 2

\begin{tabular}{|c|c|c|c|}
\hline Fracture area & $\lambda_{X} \times 10^{3} \mathrm{~mm} / \mathrm{N}$ & $\lambda_{Y} \times 10^{3} \mathrm{~mm} / \mathrm{N}$ & $\lambda \times 10^{3} \mathrm{~mm} / \mathrm{N}$ \\
\hline \multicolumn{4}{|c|}{ Axial load without regenerate } \\
\hline Medial points & 2,63 & 1,63 & 3,09 \\
\hline Lateral points & 8,66 & 1,47 & 8,79 \\
\hline \multicolumn{4}{|c|}{ Axial load with regenerate simulation } \\
\hline Medial points & 0,37 & 0,26 & 0,45 \\
\hline Lateral points & 1,00 & 0,26 & 1,03 \\
\hline \multicolumn{4}{|c|}{ Bending load without regenerate } \\
\hline Medial points & 0,40 & 1,79 \\
\hline Lateral points & 0,99 & 10,33 & 1,83 \\
\hline \multicolumn{3}{|c|}{ Bending load with regenerate simulation } \\
\hline Medial points & 0,40 & 0,60 & 0,72 \\
\hline Lateral points & 0,79 & 1,39 & 1,60 \\
\hline
\end{tabular}

According to the values of the reduced displacements obtained as a result of the tests, the permissible loads $[P]$ on the bone with a fixed fracture that do 
not cause displacements in the fracture area $[\Lambda]=1 \mathrm{~mm}$ were calculated [13]. Comparative histograms of the calculation results are shown in Fig. 2.

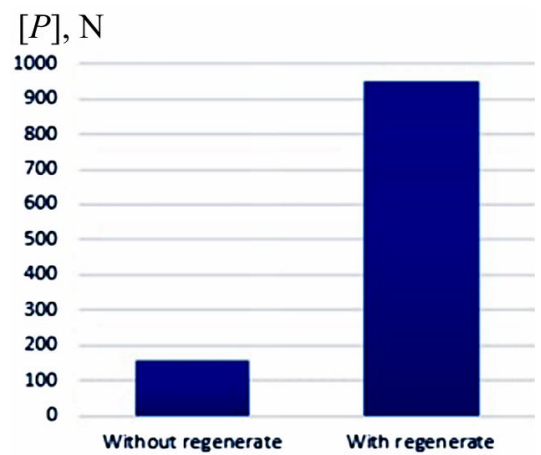

(a)



(b)

Fig. 2.Comparison of permissible loads $[P], \mathrm{N}$ on the tibia with a fracture fixed by the medial blocked plate during compression (a) and bending (b)

Presented results show that the formation of BR significantly improves the characteristics of the system "bone with a fracture - fixative - bone regenerate" (reduces movement in the fracture area and increases the permissible load on the limbs).

Tests using silicone compound. Tests were performed using compound "Siliflex 20" as a substitute for BR with a ratio of components of 100: 5 (modulus of elasticity under compression $E=0.82 \ldots 0.87 \mathrm{MPa}$ ).

Filling of diastase with compound was performed in the following way. The place of the simulated fracture on the tibia was wrapped with food film so that the latter was close to the bone. Using a syringe, the compound was collected and poured into the fracture site through a small hole. The portion of the compound remaining in the container in which the mixture was mixed was left as a control sample to check the readiness and curing of the compound. It was held for 72 hours at room temperature. Using a control sample, it was checked that the compound has hardened. The food film was removed from the sample and the extra parts of the hardened compound were removed (Fig. 1c).

After complete polymerization of the compound, the samples were tested for compression, bending and torsion according to the above method with the measurement of mutual displacements in the fracture by digital photography. The results of tests and calculations are given in Table 3.

Table 3

\begin{tabular}{|c|c|c|}
\hline \multirow{2}{*}{ Type of load } & \multicolumn{2}{|c|}{$\lambda_{X} \times 10^{3} \mathrm{~mm} / \mathrm{N}$} \\
\cline { 2 - 3 } & Without regenerate & With simulated regenerate \\
\hline Compression & $9.71 \ldots 12.1$ & $8.32 \ldots 9.47$ \\
\hline Bending & $8.81 \ldots 12.2$ & $7.33 \ldots 10.0$ \\
\hline Torsion & $29.2 \ldots 36.0$ & $17.8 \ldots 19.5$ \\
\hline
\end{tabular}


It can be seen that the presence of a simulated BR, even with such a small modulus of elasticity, reduces the displacement in the fracture by about $20 \%$ during compression and bending and by about $70 \%$ during torsion.

Calculation of permissible loads in the osteosynthesis system taking into account the presence of RCG. Schematically, the calculation system "bone with a fracture - fixative - bone regenerate" is shown in Fig. 3a. Due to the application of the axial load $P$ bone and fasteners (areas around the screws, the shift in the fastening point, etc.), plates (mostly bending), regenerate (mostly compression) are deformed.

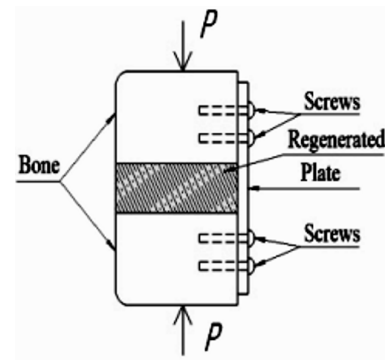

(a)

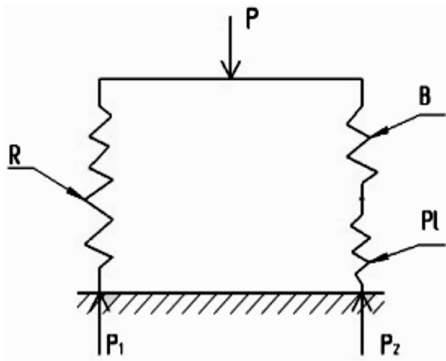

(b)

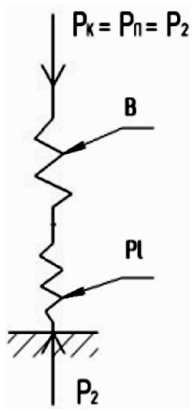

(c)

Fig. 3. System "bone with a fracture - fixative - bone regenerate" (a); calculation scheme of the osteosynthesis system with regenerate $(\mathrm{R})$ by means of elastic elements (b); system "bone with fracture (B) and fixative means (plate Pl)" (c)

This system can be reduced to the calculation scheme using the elastic elements shown in Fig. 3b. Element $\mathrm{K}$ modulates the total deformation of the bone and the fixing plate, element $\mathrm{Pl}$ - the deformation of the plate, element $\mathrm{R}$ - the deformation of the regenerate.

The following notation was introduced:

$\Delta$ - total displacement of the fracture point under the action of load $P$ (it is better to take the displacement in the extreme left fracture point as the maximum);

$P_{R}$ - load on the element R;

$P_{S}=P_{B}=P_{P l}$ - load in the elements $\mathrm{S}$ and Pl (Fig. 3b);

$\lambda=\Delta / P$ - reduced displacement of the system as a whole;

$\lambda_{R}=\Delta_{R} / P_{R}$ - reduced displacement of the regenerate;

$\lambda_{B}=\Delta_{B} / P_{B}, \quad \lambda_{P l}=\Delta_{P l} / P_{P l}$ - the displacements of the bone with fixations and plates are given.

The upper letter "e" denotes the above displacements, determined in the experiment using a sample with a given size of diastasis (distance between the parts of the fracture) and with a known modulus of elasticity. In the future we will conditionally call this sample "basic".

Values, being determined experimentally: 
$\lambda^{e}$ is the deformation of the "base" sample with the simulated regenerate;

$\lambda_{S}^{e}=\lambda_{B}^{e}+\lambda_{P l}^{e}$ is the sum of the reduced deformations of the sample without regenerate [14].

Taking into account the connection of the elements shown in Figure 3:

$$
\begin{gathered}
P \cdot \lambda=\left(P_{S}+P_{R}\right) \cdot \lambda=\Delta ; \\
P_{R} \cdot \lambda_{R}=\Delta ; \\
P_{B} \cdot \lambda_{B}+P_{P l} \cdot \lambda_{P l}=\Delta ; \\
P_{B}=P_{P l}=P_{S} ; \\
P_{S} \cdot\left(\lambda_{B}+\lambda_{P l}\right)=\Delta .
\end{gathered}
$$

We compare (5) and (1) and consider that $\lambda_{B}+\lambda_{P l}=\lambda_{S}$ :

$$
\begin{gathered}
P_{S} \cdot\left(\lambda_{B}+\lambda_{P l}\right)=P_{S} \cdot \lambda_{S}=P_{R} \cdot \lambda_{R} \\
P_{R}=P_{S} \cdot\left(\lambda_{S}-\lambda\right) / \lambda .
\end{gathered}
$$

We equate (2) and (5):

$$
P_{R} \cdot \lambda_{R}=P_{S} \cdot\left(\lambda_{B}+\lambda_{P l}\right)=\mathrm{P}_{S} \cdot \lambda_{S}
$$

and substitute (6) in (7). In the final form shows the displacement of the regenerate:

$$
\lambda_{R}=\lambda \cdot \lambda_{S} /\left(\lambda_{S}-\lambda\right)
$$

Note that the given displacements of the bone part and the plate $\left(\lambda_{S}=\lambda_{B}+\lambda_{P l}\right)$ do not depend on the size and modulus of elasticity of the regenerate. These are the characteristics of the "bone-plate" system.

Assuming that the given displacements of the regenerate are directly proportional to the distances between the fracture parts and inversely proportional to the modulus of elasticity:

$$
\lambda_{R}=\lambda_{R}^{e} \cdot\left(h / h^{e}\right) \cdot\left(E_{R}^{e} / E_{R}\right)=\lambda_{R}^{e} \cdot Q,
$$

where $Q=\left(h / h^{e}\right) \cdot\left(E_{R}^{e} / E_{R}\right)$ - coefficient depending on the size of diastasis and elastic properties of the regenerate (increase in the pliability of the regenerate layer with increasing size of diastase and decrease in the stiffness of the regenerate); $h$ is the size of the diastase in the sample being analyzed; $h^{e}$ is the size of the diastase in the test sample; $E_{R}$ - modulus of elasticity of the regenerate; $E_{R}^{e}$ - modulus of elasticity of the regenerate "base" sample; $\lambda_{R}^{e}$ reduced displacement calculated by formula (8) for the "base" sample:

$$
\lambda_{R}^{e}=\lambda^{e} \cdot \lambda_{S} /\left(\lambda_{S}-\lambda^{e}\right) \text {. }
$$

In formula (10) $\lambda^{e}$ is the displacement of the "base" sample with the size of the diastase $\mathrm{h}^{\mathrm{e}}$ and the modulus of elasticity $E_{R}$.

Note that it is not necessary to determine $\lambda_{B}$ and $\lambda_{P l}$ separately. It is sufficient to determine the total reduced displacement of the sample without regenerate

$$
\lambda_{B}+\lambda_{P l}=\lambda_{S}
$$


and use this value further in formula (10).

Displacement at the fracture site is determined by the formula:

$$
\Delta=P / C_{\text {gen }},
$$

where $C_{\text {gen }}=C_{R}+C_{S}$ - total rigidity of the system, $C_{R}$ - rigidity of the regenerate; $C_{S}$ - rigidity of the system without regenerate.

Taking into account (9)

$$
\begin{aligned}
& C_{R}=1 / \lambda_{R}=1 /\left(\lambda_{R}^{e} \cdot Q\right) ; \\
& C_{S}=1 / \lambda_{S}=1 /\left(\lambda_{B}+\lambda_{P l}\right) .
\end{aligned}
$$
form:

Given (12) - (14), the final expression for the total displacement has the

$$
\Delta=P \cdot\left(\lambda_{R}^{e} \cdot \lambda_{S} \cdot Q\right) /\left(\lambda_{R}^{e} \cdot Q+\lambda_{S}\right)=P \cdot \lambda .
$$

In (15) we replace $\lambda_{R}^{e}$ by formula (10) and obtain the final expression to determine the reduced displacement of the fracture points with a given size of the diastase and the value of the modulus of elasticity of the BR:

$$
\lambda=\lambda_{S} \cdot Q /\left(\lambda_{s} / \lambda^{e}+Q-1\right)
$$

Therefore, to calculate the displacement under load of the sample with a given diastase $h$ and the modulus of elasticity of the regenerate $E_{R}$, it is necessary to give the following tests and calculations:

1. Load the sample with a fracture with diastase $h^{e}$ and the means of fixation with the $P_{S}$ force without modeling the regenerate. Measure the displacement $\Delta_{S}$ and calculate the reduced deformation $\lambda_{S}=\Delta_{S} / P_{S}$;

2. Load the same specimen with diastase $h^{e}$ and with the simulated regenerate with modulus of elasticity $E_{R}^{e}$ ("base" specimen) with the force $P$ and measure the displacement of fracture parts $\Delta$. The modulus of elasticity $E_{R}^{e}$ is measured on a standard sample made of a material that simulates the regenerate. Calculate the reduced displacement of the breakpoints of this sample $\lambda^{e}=\Delta / P$;

3.The coefficient of influence calculated for a bone with a given fracture diastasis $h$ and a known modulus of elasticity $E_{R}$ (established by radiograph) by the formula:

$$
Q=\left(h / h^{e}\right) \cdot\left(E_{R}^{e} / E_{R}\right)
$$

4. The reduced displacement of this fracture is determined by formula (16). The values of the reduced displacements of the test specimens are given in table 3.

The above technique allows to determine the permissible loads on the bone at different stages of $\mathrm{BR}$ formation. We assume that the permissible displacements $[\Delta]$ in the fracture region are not allowed more than $1 \mathrm{~mm}$ at the size of the diastase $h_{d}=10 \mathrm{~mm}$. 
It is obvious that with increasing magnitude of diastasis, the permissible displacement increases and vice versa. We assume that the increase in $[\Delta]$ is proportional to the size of the diastase $h$. So:

$$
[\Delta]=\left[\Delta^{e}\right] \cdot\left(h / h_{d}\right) .
$$

The condition of rigidity in the presence of regenerate is obtained from (16):

$$
P \cdot\left(\left(\lambda_{S} \cdot R\right) /\left(\lambda_{S} / \lambda^{e}+Q-1\right)\right) \leq[\Delta] .
$$

Permissible load is calculated by the formula:

$$
[P]=[\Delta] \cdot\left(\left(\lambda_{S} \cdot Q\right) /\left(\lambda_{S} / \lambda^{e}+Q-1\right)\right)^{-1} .
$$

The values of permissible displacements, calculated according to formula (19) and permissible compressive loads for bones with a fracture at different weeks of rehabilitation with the corresponding modulus of elasticity of the regenerate [15] are given on Fig. 4.

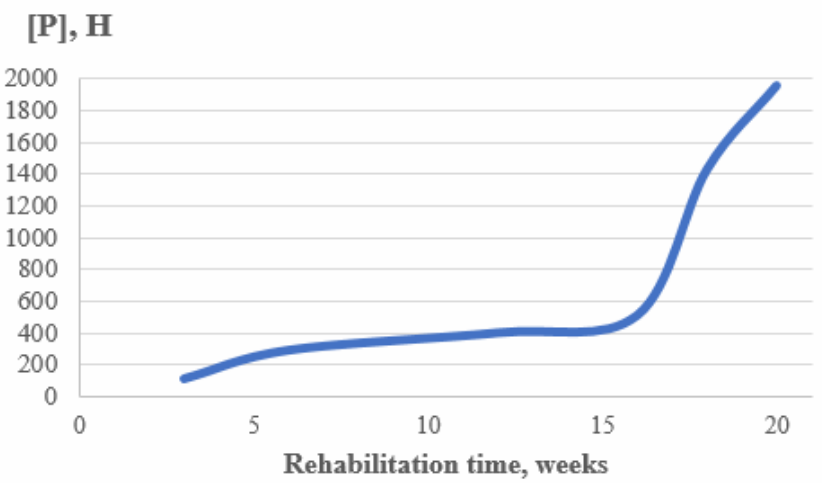

Fig. 4. Permissible compressive loads $[P]$ on the tibia with a fracture fixed by a medial blocked plate, at different times of rehabilitation

It should be noted that the given values of permissible loads are obtained by a formal approach to the calculation of elastic systems, adopted in technical mechanics. These results, as well as the proposed methods for assessing the impact of BR on the functional characteristics of OS systems, can be further used by traumatologists only after comprehensive biomechanical studies of these systems.

The complexity of the issue of increasing physiological loads on bones with fractures in the state of fusion is due, inter alia, to the lack of reliable and unambiguous information about the permissible deformations (displacements) in the fracture area under external loads on the extremities.

\section{Conclusion.}

1. A method for estimating the level of displacement in bone fractures under the action of external forces at the stage of bone regeneration formation has been developed. It is possible to assess the contribution of loads of different directions relative to the longitudinal axis of the bone in the overall 
level of deformation of the osteosynthesis system and to determine the dangerous directions of loads and their permissible levels.

2. Deformation of "bone with fracture and fixation" systems at the stages of bone regeneration under the action of compression, bending and torsion has been studied. It is established that the formed regenerate significantly increases the rigidity of the system "bone with a fracture - bone regenerate - a means of fixation", which increases the level of permissible loads on the extremities at different stages of treatment.

3. To take into account the contribution of the regenerate to the mutual displacements of fracture points and to estimate the permissible loads on the bone, a sufficiently simple mathematical model has been developed. It allows to calculate permissible loads that can be applied to the limb, taking into account known fracture points' permissible mutual displacements.

\section{REFERENCES}

1. Ermak A.A. Sposib otsinky vplyvu reheneratsiyi kistkovoyi tkanyny na zhorst kistfiksovanykh perelomiv (A method of assessing the impact of bone regeneration on the rigidity of fixed fractures)/ A.A. Ermak, O.S. Musiienko, M.S. Shidlovsky, O.P. Zakhovaiko //Innovatsiyi molodi $\mathrm{V}$ mashynobuduvanni (Youth Innovations in Mechanical Engineering) /K.: Igor Sikorsky Kyiv Polytechnic Institute, № 1, 2019. P.39-42.

2. Lisachenko Yu.A. Vplyv reheneratu kistkovoyi tkanyny na zhorst kistfiksatsiyi perelomiv kistok (Influence of bone regeneration on the rigidity of fixation of bone fractures) / Yu. A. Lisachenko, O.S. Musiienko, A.A. Ermak, O.P. Zakhovaiko, M.S. Shidlovsky// Innovatsiyimolodi v mashynobuduvanni (Youth Innovations in Mechanical Engineering) /K.: Igor Sikorsky Kyiv Polytechnic Institute, № 2, 2020. P.29-40.

3. Bumeyster V.I. Suchasnyy pohlyad na reparatyvnyy osteohenez (Modern view on reparative osteogenesis) / V. I. Bumeyster, M. V. Pohorelov // Svitmedytsyny ta biolohiyi (The world of medicine and biology) / №4, 2008. P.104-109.

4. Ivanov O.M. Zastosuvannya kriokonservovanoho khoriona pry rozladakh reparatyvnoho osteohenezu (eksperymentalno-klinichne doslidzhennya) (Application of cryopreserved chorion in disorders of reparative osteogenesis (experimental-clinical study))dys. ... kand. med. nauk: 14.01.21 / Ivanov Oleksiy Mykolayovych; Kharkivskyy natsionalnyy medychnyy universytet. Kharkiv, 2016. 223 p.

5. Huminsky Yu.Y. Suchasni aspekty ekomorfolohiyi reparatyvnoho osteoheneza (Modern aspects of ecomorphology of reparative osteogenesis) / Yu. Y. Huminsky, O.V. Korenkov // Visnyk Sumskoho derzhavnoho universytetu 2 / №1, 2009. P.17-23.

6. Shidlovskiy M.S. Eksperymentalni doslidzhennya zasobiv osteosyntezu (Experimental studies of osteosynthesis) / M.S.Shidlovskiy, A.M. Laksha. -K.: Lenvit, 2017. - 277 p.

7. Omelchenko T.M. Imitatsiyne kompyuterne modelyuvannya y naturnestendove doslidzhennya napruzheno-deformovanoho stanu biomekhanichnoyi systemy «fiksator-kistka» pry nadkistochkovykh koryhuvalnykh osteotomiy / T.M. Omelchenko, O.A. Buryanov, A.P. Lyabakh, M.S. Shydlovskiy, V.O. Yeshchenko, M.M. Dyman // Ortopediya, travmatologiya I protezirovaniye (Orthopedics, traumatology and prosthetics) / № 2, 2019. P.19-26.

8. Omelchenko T.M. Fizyko-mekhanichni vlastyvosti trabekulyarnoyi kistkovoyi tkanyny kistok homilkovostopnoho suhloba (ekserymentalno-klinichne doslidzhennya) (Physico-mechanical properties of trabecular bone tissue of the ankle bones (experimental-clinical study)) / T.M. Omelchenko, O.A. Buryanov, A.P. Lyabakh, V.B. Mazevich, O.S. Musiienko, M.S. Shydlovskiy// Visnykortopediyi, travmatolohiyi ta protezuvannya (Bulletin of orthopedics, traumatology and prosthetics) / № 2, 2017. P.66-72.

9. Shidlovskiy M. Deformation of fixation means used in bone fractures of the extermities / M. Shidlovskiy, M. Dyman, O. Zakhovayko, T. Omelchenko, A. Turchin // Series on Biomechanics, Vol.33, № 1, 2019. - P. 59-68.

10. Shidlovskiy $M$. The tibial fractures fixation system deformation characteristics / $M$. Shidlovskiy, M. Dyman, T. Omelchenko // Mechanics and Advanced Technologies№ 3 (84), 2018, P. 52-60. 
11. Buryanov O.A. Deformatsiyni kharakterystyky system fiksatsiyi, shcho zastosovuyutsya pry perelomakh ta korektsiynykh osteotomiyakh dystalnoho viddilu velykohomilkovoyi kistky (Deformation characteristics of fixation systems used in fractures and corrective osteotomies of the distal tibia) / O.A. Buryanov, M.S. Shydlovskiy, T.M. Omelchenko, M.M. Dyman, O.S. Musiienko // Litopystravmatolohiyi ta ortopediyi (Chronicle of traumatology and orthopedics), № 1-2(35-36), 2017. P.129-133.

12. Ermak A.A. Spivvidnoshennya deformatsiy v elementakh zasobiv fiksatsiyi perelomiv (The ratio of deformations in the elements of the means of fixing fractures) / A.A. Ermak, M.M. Dyman, M.S. Shidlovsky // Innovatsiyimolodi v mashynobuduvanni (Youth Innovations in Mechanical Engineering)/K.: Igor Sikorsky Kyiv Polytechnic Institute, 2018. P.1-4.

13. Shidlovskiy M.S. Kryteriyi dlya vyznachennya dopustymykh navantazhen nakistky $\mathrm{z}$ fiksovanymy perelomamy (Criteria for determining the allowable loads on bones with fixed fractures) / M.S. Shidlovskiy, M.M. Dyman, O. P. Zakhovayko, T.M. Omelchenko // Litopystravmatolohiyi ta ortopediyi (Chronicle of traumatology and orthopedics), № 3-4 (3940), 2018. P.76-81.

14. DymanM. M. Deformivnist system osteosyntezu z vrakhuvannyam vydu navantazhen (Deformability of osteosynthesis systems taking into account the type of loads) dys. kand. tekhn. nauk: 01.02.04 / M.M. Dyman. Kyiv, 2019. 208 p.

15. Begun P.I. Issledovaniye sostoyaniya organov I struktur chelovecheskogo organizma pri reabilitatsii I rekonstruktsii (Study of the state of organs and structures of the human body during rehabilitation and reconstruction) / P.I. Begun, O.V. Krivokhizhina, E.A. Lebedeva, P.I. Tolkachev, T.V. Sergeev, O.V. Shchepilina // Visnyk Chernihivskoho natsionalnoho pedahohichnoho universytetu. Seriya: Pedahohichninauky. Fizychnevykhovannya ta sport, Vyp. 129, 2015. P. 18-25.

Стаття надійшла 28.09.2021

\section{Шидловський М.С., Мусієнко О.С., Заховайко О.П., Лисаченко Ю. А. \\ ВПЛИВ РЕГЕНЕРАТУ КІСТКОВОЇ ТКАНИНИ НА ЖОРСТКІСТЬ ФІКСАЦІЇ ПЕРЕЛОМІВ КІСТОК}

На основі експериментальних досліджень запропоновано аналітичний метод для оцінки впливу регенерату кісткової тканини на жорсткість системи остеосинтезу.

Розроблено та випробувано методику експериментального визначення переміщень в області перелому під дією навантажень з врахуванням регенерату.

Проведено ряд експериментів при стиску, згині та крученні та визначенню деформаційні характеристики систем без регенерату та при його наявності.

Описано результати експериментів, пов'язаних з впливом регенерату кісткової тканини, що утворюється протягом зрощування переломів, на механічні характеристики системи «кістка з переломом - засіб фіксації». Для оцінки впливу регенерату кісткової тканини розроблений та реалізований метод дослідження деформування систем остеосинтезу із застосуванням способу моделювання регенерату кісткової тканини полімерним матеріалом із заданими властивостями.

Із застосуванням умови жорсткості, одержано вираз для розрахунку допустимих навантажень, що не приводять до виникнення небезпечних переміщень точок перелому.

Розраховано приведені деформації та допустимі навантаження для систем «кістка 3 переломом - засіб фіксації» на різних етапах регенерації кісткової тканини при дії стиску, згину та кручення.

Встановлено, що утворений регенерат суттєво підвищує жорсткість системи «кістка 3 переломом - кістковий регенерат - засіб фіксації», що збільшує рівень допустимих навантажень на кінцівки на різних стадіях лікування.

Дані випробувань та розрахунків можуть будуть використані для удосконалення методів лікування пошкоджених кінцівок на проміжних та заключних стадіях зрощування переломів.

Ключові слова: регенерат кісткової тканини, жорсткість систем, остеосинтез, біомеханічні характеристики, великогомілкова кістка, стиск, згин, кручення, допустиме навантаження. 


\section{Шидловский Н.С., Мусиенко О.С., Заховайко А.А., Лысаченко Ю. А.}

\section{ВЛИЯНИЕ РЕГЕНЕРАТА КОСТНОЙ ТКАНИ НА ЖЕСТКОСТЬ ФИКСАЦИИ ПЕРЕЛОМОВ КОСТЕЙ}

На основе экспериментальных исследований предложен аналитический метод для оценки влияния регенерата костной ткани на жесткость системы остеосинтеза.

Разработано и испытано методику экспериментального определения перемещений в области перелома под действием нагрузок с учетом регенерата.

Проведен ряд экспериментов при сжатии, изгибе и кручении и определению деформационные характеристики систем без регенерата и при его наличии.

Описаны результаты экспериментов, связанных с воздействием регенерата костной ткани, образуемой в течение сращивания переломов, на механические характеристики системы «кость с переломом - средство фиксации». Для оценки влияния регенерата костной ткани разработан и реализован метод исследования деформирования систем остеосинтеза с применением способа моделирования регенерата костной ткани полимерным материалом с заданными свойствами.

С применением условия жесткости, получено выражение для расчета допустимых нагрузок, что не приводят к возникновению опасных перемещений точек перелома.

Рассчитано приведенные деформации и допустимые нагрузки для систем «кость с переломом - средство фиксации» на разных этапах регенерации костной ткани при действии сжатия, изгиба и кручения.

Установлено, что образованный регенерат существенно повышает жесткость системы «кость с переломом - костный регенерат - средство фиксации», что увеличивает уровень допустимых нагрузок на конечности на разных стадиях лечения.

Данные испытаний и расчетов могут быть использованы для совершенствования методов лечения поврежденных конечностей на промежуточных и заключительных стадиях сращивания переломов.

Ключевые слова: регенерат костной ткани, жесткость систем, остеосинтез, биомеханические характеристики, большеберцовая кость, сжатие, изгиб, кручение, допустимая нагрузка.

УДК 620.171.3:616.71-001.5

Шидловський М.С., Мусієнко О.С., Заховайко О.П., Лисаченко Ю. А. Вплив регенерату кісткової тканини на жорсткість фіксації переломів кісток/ Опірматеріалів i теоріяспоруд: наук.-тех. збірн. - К.: КНУБА, 2021. - Вип. 107. - С. 89-102. - Англ.

На основі експериментальних досліджень запропоновано аналітичний метод для очінки впливу регенерату кісткової тканини на жорсткість системи остеосинтезу. Розроблено та випробувано методику експериментального визначення переміщень в області перелому під дією навантажень з врахуванням регенерату.

Табл. 3. Іл. 4. Бібліогр. 15 назв.

UDC 620.171.3:616.71-001.5

Shidlovskiy M.S., Musiienko O.S, Zakhovaiko O.P., Lisachenko Yu. A. Influence of bone tissue regenerate on rigidity of fractures fixation/ Strength of Materials and Theory of Structures: Scientific-and-technical collected articles. - K.: KNUBA, 2021. - Issue 107. -P. 89-102.

Based on experimental studies, an analytical method is proposed for an estimation of the influence of a regenerate of a bone fabric on rigidity of the system of osteosynthesis. A method for the experimental determination of displacements in the fracture region under the action of loads taking into account the regenerate has been developed and tested.

Tabl. 3. Fig. 4. Ref. 15.

УДК 620.171.3:616.71-001.5

Шидловский Н.С., Мусиенко О.С., Заховайко А.А., Лисаченко Ю. А.Влияние регенерата костной ткани на жесткость фиксации переломов костей/ Сопротивление материалов и теория сооружений: науч.-тех. сборн. - К.: КНУСА, 2021. - Вип. 107. - С. 89-102. - Англ.

На основе экспериментальных исследований предложен аналитический метод для оиенки влияния регенерата костной ткани на жесткость системы остеосинтеза. Разработана и испытана методика экспериментального определения перемещений в области перелома под действием нагрузок с учетом регенерата.

Табл. 3. Ил. 4. Библиогр. 15 назв. 
Автор (вчений ступінь, вчене звання, посада):кандидат технічних наук, доцент кафедри динаміки і міцності машин та опору матеріалів КПІ ім. Ігоря Сікорського, Шидловський Микола Сергійович.

Адреса: 03056 Україна, м. Київ, просп. Перемоги 37, Національний технічний університет України “Київський політехнічний інститут імені Ігоря Сікорського”, кафедра динаміки і міцності машин та опору матеріалів.

Мобільний тел.: +38(063) 830-74-22.

Імейл: n_shidlovsky@ukr.net

ORCID ID: https://orcid.org/0000-0003-0307-9044

Автор (вчений ступінь, вчене звання, посада):аспірантка кафедри динаміки і міцності машин та опору матеріалів КПІ ім. Ігоря Сікорського, Мусієнко Ольга Станіславівна.

Адреса: 03056 Україна, м. Київ, просп. Перемоги 37, Національний технічний університет України “Київський політехнічний інститут імені Ігоря Сікорського”, кафедра динаміки і міцності машин та опору матеріалів.

Робочий тел.: +38(044) 204-95-36.

Мобільний тел.: +38(098) 712-35-09.

Імейл:olga.musinko@gmail.com

ORCID ID:https://orcid.org/0000-0001-8255-3909

Автор (вчений ступінь, вчене звання, посада): кандидат технічних наук, доцент кафедри динаміки і міцності машин та опору матеріалів КПІ ім. Ігоря Сікорського, Заховайко Олександр Панасович.

Адреса: 03056 Україна, м. Київ, просп. Перемоги 37, Національний технічний університет України “Київський політехнічний інститут імені Ігоря Сікорського", кафедра динаміки і міцності машин та опору матеріалів.

Мобільний тел.: +38(099) 561-94-52.

Імейл: zakhov1911@gmail.com

ORCID ID:https://orcid.org/0000-0002-6841-3667

Автор (вчений ступінь, вчене звання, посада): студент кафедри динаміки і міцності машин та опору матеріалів КПІ ім. Ігоря Сікорського, Лисаченко Юрій Андрійович.

Адреса: 03056 Україна, м. Київ, просп. Перемоги 37, Національний технічний університет України "Київський політехнічний інститут імені Ігоря Сікорського", кафедра динаміки i міцності машин та опору матеріалів.

Мобільний тел.: +38(050) 212-34-24. 